\title{
OPTIMASI FORMULASI NORI BROKOLI DENGAN MENGGUNAKAN PROGRAM DESIGN EXPERT METODA MIXTURE D-OPTIMAL
}

\author{
Thomas Ghozaly \\ Nana Sutisna Achyadi \\ Miftahul Awaluddin A

\begin{abstract}
Program Studi Teknologi Pangan, Fakultas Teknik, Universitas Pasundan, J1. Dr.Setiabudi No 93, Bandung, 40153, Indonesia
\end{abstract} \\ Email: thomasgozaly@unpas.ac.id
}

\begin{abstract}
The purpose of this research was to obtain the optimal formulation of making nori broccoli with Design Expert program using the D-Optimal method. This research was conducted to produce characteristic of chemical, physics, and organoleptic in accordance with the desire so that generated the selected formulation. The response in this research was chemical analysis of water content, fiber content and vitamin C content, physics response is tensile strength test, and organoleptic test with attributes of color, flavor,texture, and taste. The result of this research was obtain 11 formulation offered for produce one optimal formulation (selected) based on desirability value 0,825 was broccoli $70 \%$, water $16,50 \%$, carrageenan $3 \%$, and other additional materials as fixed variable consist of sesame oil $2,9 \%$, salt $1,4 \%$, sugar $3,3 \%$, dried ebi $2 \%$, and glycerol $0,9 \%$. The selected sample has conducted an analysis of antioxidant activity and tensile strength test. The results of laboratory analysis against water content $12,63 \%$; fiber content $11,44 \%$; vitamin $\mathrm{C}$ content 5,38\%; organoleptic test attribute of taste 3,60; texture 4,20; flavor 3,80; and color 4 . The results of laboratory analysis approach of design expert program prediction method of d-optimal. For the result of antioxidant activity in raw material was $239,485 \mathrm{ppm}$ and product was $8031,786 \mathrm{ppm}$ and the average result of tensile strength test in the product was $129,68 \mathrm{kPa}$.
\end{abstract}

Keyword : Design Expert, Nori broccoli, Formulation, Optima

\section{Pendahuluan}

Kurangnya masyarakat akan konsumsi makanan sehat perlu mendapatkan perhatian lebih dari semua pihak. Salah satu cara untuk meningkatkan pola konsumsi sehat adalah dengan lebih memperbanyak konsumsi sayuran. Didalam sayuran terdapat banyak sekali zat gizi terutama vitamin dan mineral yang sangat berguna untuk tubuh.

Dari data Kemtan, tingkat konsumsi sayuran penduduk Indonesia tahun 2005 sebesar 35,30 $\mathrm{kg} / \mathrm{kapita} / \mathrm{tahun}$, kemudian tahun 2006 sebesar 34,06 $\mathrm{kg} / \mathrm{kapita} / \mathrm{tahun}$, dan tahun 2007 meningkat sebesar $40,90 \mathrm{~kg} / \mathrm{kapita} / \mathrm{tahun}$. Standar konsumsi sayur yang direkomendasikan FAO sebesar $73 \mathrm{~kg} / \mathrm{kapita} / \mathrm{tahun}$, sedangkan standar kecukupan untuk sehat sebesar $91,25 \mathrm{~kg} / \mathrm{kapita} / \mathrm{tahun}$. Dilihat dari data tersebut Indonesia jauh tertinggal dari negara lain seperti Singapura $120 \mathrm{~kg} / \mathrm{kapita} / \mathrm{tahun}$, China 270/kapita/tahun, Vietnam 85kg/kapita/tahun dan Kamboja 109 kg/kapita/tahun. (ASEIBSSINDO, 2015).

Diversifikasi pangan adalah salah satu cara untuk meningkatkan tingkat konsumsi sayuran. Dilihat dari masyarakat yang sangat gemar mengkonsumsi snack atau makanan ringan dalam kesehariannya, maka dibuat snack dari sayuran.
Saat ini masyarakat Indonesia menunjukan ketertarikan yang luar biasa pada nori. Hal ini dapat dibuktikan dengan semakin banyaknya produk nori dalam kemasan yang di jual di pasar-pasar swalayan dan nori yang dijadikan bungkusan makanan-makanan yang berasal dari korea seperti sushi, origin, dan sebagainya. Namun karena masih sedikitnya ketersediaan Poryphyra sebagai bahan baku utama pembuatan nori, sebagian besar produk nori yang beredar di Indonesia masih merupakan produk impor yang diproduksi oleh perusahaan asing sehingga berdampak pada mahalnya produk.

Akibat mahalnya harga rumput laut sebagai bahan baku pembuatan Nori sehingga perlu di diversifikasikan bahan baku pembuatan Nori yakni dengan bahan serupa yang dapat membentuk gel dan dikeringkan supaya membentuk lembaran. Salah satu alternatif yang dapat menyerupai rumput laut lembaran (nori) adalah dibuatnya Nori brokoli. Nori adalah nama dalam bahasa Jepang untuk bahan makanan berupa lembaran rumput laut yang dikeringkan. Nori digunakan sebagai hiasan dan pembungkus berbagai macam masakan Jepang, lauk sewaktu makan nasi, dan bahan camilan/snack. 
Nori merupakan lembaran rumput laut yang dikeringkan atau dipanggang (Korringa, 1976), sedangkan menurut Giury (2006), nori adalah salah satu produk olahan rumput laut alami yang dikeringkan dan merupakan produk olahan dari rumput laut merah (Rhodophyta). Nori adalah sediaan berupa rumput laut yang dikeringkan berbahan baku rumput laut merah jenis Poryphyra yang dapat ditambahkan bumbu di dalamnya seperti ajitsuke nori. Masyarakat Jepang telah mengkonsumsi nori sejak abad ke-8. Konsumen nori tertinggi adalah negara Jepang yaitu sebesar $75 \%$ dari total produksi rumput laut .

Tuntutan masyarakat kini tidak hanya membutuhkan pangan pokok saja, namun juga produk pangan alternatif yang mudah disajikan, bergizi, aman, memiliki karakteristik organoleptik yang menarik serta terjangkau. Salah satu produk pangan tersebut ialah snack product atau yang biasa disebut makanan ringan.

Bahan penstabil adalah bahan yang digunakan dalam industri makanan untuk mengikat air yang terdapat dalam adonan. Tujuan penambahan bahan penstabil (stabilizer) pada produk nori adalah meningkatkan stabilitas emulsi, meningkatkan daya ikat produk, meningkatkan flavor, mengurangi pengerutan selama pemasakan, meningkatkan karakteristik produk, dan mengurangi biaya formulasi (Anjarsari, 2010).

Karagenan dapat diekstraksi dari protein dan lignin rumput laut dan dapat digunakan dalam industri pangan karena karakteristiknya yang dapat berbentuk gel, bersifat mengentalkan, dan menstabilkan material. Polisakarida tersebut tidak dapat dimakan oleh manusia dan tidak memiliki nutrisi yang diperlukan oleh tubuh. Oleh karena itu, karagenan hanya digunakan dalam industri pangan karena fungsi karakteristiknya yang dapat digunakan untuk mengendalikan kandungan air dalam

bahan pangan utamanya, mengendalikan tekstur, dan menstabilkan makanan (Suherman, 2012).

Produk nori memiliki karakteristik yang hampir sama dengan produk edible film dan fruit leather atau vegetable leather. Oleh karena itu Nori dibuat dengan menggunakan puree brokoli dengan penambahan karagenan sebagai bahan penstabil. Beberapa bahan penstabil dan pengental juga termasuk dalam kelompok bahan pembentuk gel. Contoh-contoh dari bahan pembentuk gel antara lain asam alginat, sodium alginat, kalium alginat, kalsium alginat, agar, karagenan, locust bean gum, pektin dan gelatin (Raton and Smooley, 1993).

Karagenan yang digunakan dalam penelitian ini yaitu jenis kappa karagenan hasil ekstraksi dari rumput laut jenis Eucheuma Cottonii, karena dapat membentuk gel yang kuat dibandingkan jenis iota dan lambda.

Program linier salah satu teknik optimasi yang banyak berkaitan dengan penggunaan sumber daya, mulai dikembangkan oleh George Dantzig pada tahun
1947 dengan suatu teknik yang disebut Metode Simplex (Prabawa, 2013). Salah satu software yang dapat digunakan dalam penentuan formulasi secara optimal adalah Design Expert. Digunakan untuk optimasi proses dalam respon utama yang diakibatkan oleh beberapa variabel dan tujuannya adalah optimasi respon tersebut. Design Expert menyediakan beberapa pilihan desain dengan fungsinya masing-masing salah satunya adalah Mixture Design yang berfungsi untuk menemukan formulasi optimal (Bas dan Boyaci, 2007).

Penelitian ini menggunakan program Design Expert yang mempunyai kelebihan di bandingkan program lainnya, program ini akan mengoptimasikan formulasi dengan beberapa variabel yang dinyatakan dalam satuan respon, menu mixture yang dipakai yang dikhususkan untuk mengolah formulasi dan metoda doptimal yang mempunyai sifat fleksibilitas yang tinggi dalam meminimalisasikan masalah dan kesesuaian dalam menentukan jumlah batasan bahan yang berubah lebih dari 2 respon (Nugraha, 2014).

Maksud penelitian ini adalah menentukan formulasi optimal dari nori brokoli dengan menggunakan program Design Expert Metode Mixture D-Optimal.

Tujuan penelitian ini adalah untuk menghasilkan formulasi yang optimal pada pembuatan nori brokoli dengan menggunakan program Design Expert Metode D-Optimal.

\section{Metode Penelitian}

Metode penelitian yang dilakukan terdiri dari dua tahap, yaitu penelitian pendahuluan dan penelitian utama.

Tujuan dari penelitian pendahuluan ini adalah pertama untuk mengetahui kandungan kimia (nutrisi) yang ada pada bahan baku (brokoli) diantaranya antioksidan, kadar vitamin C, kadar serat, dan kadar air, agar pada saat pengujian sampel produk jadi dapat diketahui berapa penurunannya selama mengalami proses pengolahan. Serta kedua untuk menentukan variabel berubah dan respon kimia yang akan dimasukan pada program design expert.

Pada penelitian utama peneliti memasukan data variable berubah yang kemudian akan diolah oleh program design expert menghasilkan 11 formulasi . Setelah itu membuat produk dari 11 formulasi tersebut dan melakukan analisis terhadap semua produk. Kemudian memasukan data hasil analisis kedalam program design expert sehingga nantinya akan menghasilkan 1 formulasi terpilih yang optimal.

Respon kimia yang dilakukan terhadap produk selai buah murbei adalah : Ananlisis Vitamin C metode Iodometri, Analisis Kadar Air metode Gravimetri, Analisis Kadar Serat metode Gravimetri dan, Antioksidan (bahan baku dan produk terpilih) metode DPPH. 
Respon fisika yang dilakukan adalah menguji kuat tarik (tensile strenght)

Respon Organoleptik dilakukan untuk mengetahui tingkat kesukaan dari panelis terhadap produk. Uji organoleptik ini dilakukan dengan metode penerimaan yaitu skala mutu hedonik, dimana kriteria penilaian berdasarkan tingkat kesukaan panelis terhadap karakteristik dari Nori Brokoli

\section{Hasil Penelitian}

\section{Hasil Penelitian Pendahuluan}

Penelitian pendahuluan ini terdiri dari analisis bahan baku (brokoli segar) dan analisis sampel kontrol nori merk "Mamasuka" dengan parameter respon antioksidan, kadar air, kadar serat dan kadar vitamin C serta pembuatan Nori Brokoli dengan 11 formulasi yang diberikan oleh program design expert metoda mixture d-optimal.

Tabel 1. Hasil Analisis Kadar Air, Kadar Serat, dan Kadar Vitamin C pada Brokoli Segar

\begin{tabular}{|c|c|}
\hline Parameter & Hasil \\
\hline Kadar air & $85,20 \%$ \\
\hline Kadar serat & $6,72 \%$ \\
\hline Kadar Vitamin C & $\begin{array}{c}82,77 \mathrm{mg} \text { vit.C/100gram } \\
\text { sampel }\end{array}$ \\
\hline
\end{tabular}

Tabel 2. Hasil Analisis Aktivitas Antioksidan pada Brokoli Segar

\begin{tabular}{|c|c|}
\hline Parameter & $\begin{array}{c}\text { Hasil Rata-rata Nilai } \\
\mathrm{IC}_{50}(\mathrm{ppm})\end{array}$ \\
\hline Aktivitas antioksidan & 239,485 \\
\hline
\end{tabular}

Tabel 3. Hasil Analisis Kadar Air, Kadar Serat, dan Kadar Vitamin C pada Sampel Kontrol Nori Merk "Mamasuka"

\begin{tabular}{|c|c|}
\hline Parameter & Hasil \\
\hline Kadar air & $5,84 \%$ \\
\hline Kadar serat & $80,87 \%$ \\
\hline Kadar vitamin C & $2,05 \mathrm{mg} / 100$ gram sampel \\
\hline
\end{tabular}

Tabel 4. Hasil Analisis Kimia dan Uji Organoleptik Nori Brokoli

\begin{tabular}{|c|c|c|c|c|c|c|c|}
\hline Formulasi & Air $(\boldsymbol{\%})$ & Serat $(\boldsymbol{\%})$ & $\begin{array}{c}\text { Vitamin C } \\
(\boldsymbol{\%})\end{array}$ & Warna & Rasa & Tekstur & Aroma \\
\hline 1 & 13.04 & 11.42 & 5.11 & 4.44 & 3.53 & 3.53 & 3.63 \\
\hline 2 & 14.43 & 11.40 & 4.67 & 4.57 & 3.57 & 3.77 & 3.63 \\
\hline 3 & 13.87 & 12.01 & 4.71 & 4.47 & 3.90 & 3.63 & 3.73 \\
\hline 4 & 11.77 & 9.88 & 4.48 & 3.90 & 3.97 & 4.06 & 3.77 \\
\hline 5 & 12.75 & 10.83 & 4.84 & 3.80 & 3.07 & 4.00 & 3.90 \\
\hline 6 & 10.11 & 12.05 & 4.05 & 3.70 & 4.23 & 4.20 & 3.60 \\
\hline 7 & 12.38 & 9.62 & 3.62 & 4.23 & 4.10 & 3.93 & 4.13 \\
\hline 8 & 12.15 & 9.04 & 3.70 & 4.53 & 3.80 & 3.96 & 4.23 \\
\hline 9 & 9.66 & 12.15 & 3.99 & 4.03 & 4.00 & 3.77 & 4.07 \\
\hline 10 & 10.01 & 8.84 & 4.53 & 4.37 & 4.17 & 4.03 & 4.33 \\
\hline 11 & 7.85 & 9.53 & 4.15 & 3.63 & 3.60 & 3.57 & 3.63 \\
\hline
\end{tabular}

(Sumber : Program Design Expert Metoda D-Optimal)

\section{Hasil Penelitian Utama}

Penelitian utama merupakan penelitian lanjutan dari penelitian pendahuluan yang diawali dengan pembuatan Nori Brokoli menggunakan bahan dan alat yang telah dijelaskansebelumnya, analisis kimia, organoleptik Nori Brokoli, optimasi Nori Brokoli, pengolahan, dan analisis data.

Pembuatan Nori Brokoli berbahan baku brokoli, air, dan karagenan sebagai variabel berubah dilakukan sesuai formulasi menggunakan design expert yang merupakan perangkat lunak software) yang menyediakan rancangan percobaan (design of experiment) untuk melakukan optimasi terhadap rancangan produk, pengolahan dan analisis data (Suanda, 2011).

Program design expert metoda d-optimal merupakan salah satu teknik analisis kuantitatif optimasi proses yang menggunakan model matematika. Tujuan dari program design expert metoda $d$-optimal ini adalah untuk menentukan formulasi optimal dalam pembuatan nori brokoli dan dihasilkan nori brokoli yang sesuai dengan standar yang ada serta dapat diterima oleh konsumen.

Analisis pengolahan data yang digunakan dalam penelitian ini adalah mixture design dengan rancangan 
d-optimal. Produk nori brokoli dihasilkan selanjutnya diamati secara kimia (kadar air, kadar serat, kadar vitamin C,) dan uji organoleptik terhadap tingkat kesukaan (warna, aroma, rasa, dan tekstur)

\section{Kadar Air}

Berdasarkan lampiran Tabel 28 ANOVA metode Mixture D-Optimal kadar air Nori Brokoli, A menyatakan brokoli, B menyatakan air, dan C menyatakan karagenan. Term yang terdiri satu huruf dinamakan variabel tunggal menyatakan efek linear sedangkan term yang terdiri dari dua huruf dinamakan dua variabel yang menyatakan efek interaksi.

Hasil analisis sidik ragam atau uji anova dapat dilihat dilampiran pada Tabel 28 menunjukkan formula yang dibuat significant / berpengaruh nyata (probabilitas $<0.05$ ) terhadap kadar air yang diuji dengan selang kepercayaan $95 \%$. Analisis sidik ragam yang dilakukan oleh program Design Expert metode Mixture D-Optimal pada nilai respon kimia kadar air terhadap formula yang dibuat, menunjukkan model yang dibuat adalah signifikan (probabilitas <0.05), pada selang kepercayaan $95 \%$ dengan nilai $\mathrm{p}=0,0002$. Artinya formula yang dibuat berpengaruh nyata terhadap respon uji skor kadar air, sehingga nilai respon tersebut dapat digunakan untuk proses optimasi yaitu untuk mendapatkan produk dengan karakteristik yang optimum. Kadar air yang dihasilkan dari setiap formulasi memiliki rentang nilai yang lumayan berbeda dan bervariatif atau berbeda nyata sehingga nilai kadar protein dapat digunakan untuk proses optimasi formulasi. Grafik di atas menunjukkan formulasi optimal berdasarkan respon kadar air yang diprediksi oleh grafik ini sebesar 13,48\% dimana batas bawah kadar protein dari keseluruhan formulasi yaitu 7,85\% dan batas atas sebesar $14,43 \%$. Untuk mencapai nilai kadar air sesuai dengan yang diprediksikan oleh program pada pengaplikasian produk Nori Brokoli dapat dilihat pada Gambar 19 dengan menggunakan brokoli $70 \%$, air $16,5 \%$, dan karagenan $3 \%$

Grafik formulasi optimal berdasarkan respon kadar air dapat dilihat pada Gambar 3.

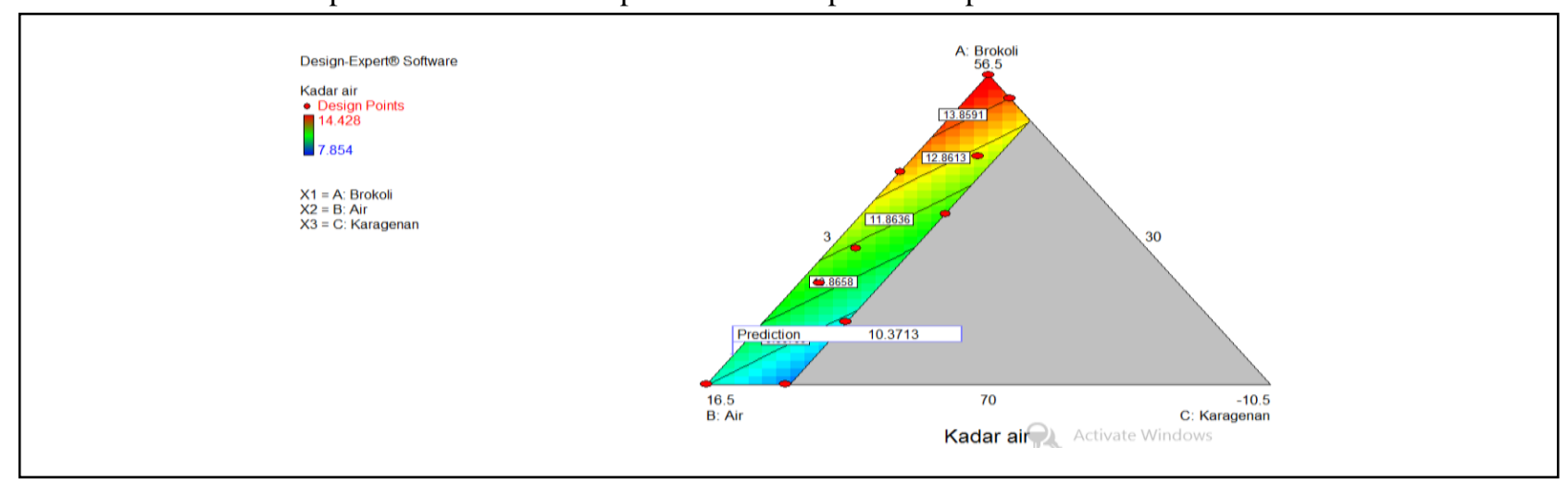

Gambar 3. Grafik Formulasi Optimal Berdasarkan Respon Kadar Air

\section{Kadar Serat}

Berdasarkan lampiran Tabel 35 ANOVA metode Mixture D-Optimal kadar serat Nori Brokoli, A menyatakan brokoli, B menyatakan air, dan menyatakan karagenan. Term yang terdiri satu huruf dinamakan variabel tunggal menyatakan efek linear sedangkan term yang terdiri dari dua huruf dinamakan dua variabel yang menyatakan efek interaksi. Hasil analisis sidik ragam atau uji anova dapat dilihat dilampiran pada Tabel 35 menunjukkan formula yang dibuat significant / berpengaruh nyata (probabilitas<0.05) terhadap kadar serat yang diuji dengan selang kepercayaan $95 \%$. Analisis sidik ragam yang dilakukan oleh program Design Expert metode
Mixture D-optimal pada nilai respon kimia kadar serat terhadap formula yang dibuat, menunjukkan model yang dibuat adalah signifikan (probabilitas $<0.05$ ), pada selang kepercayaan $95 \%$ dengan nilai $\mathrm{p}=0,0256$. Artinya formula yang dibuat berpengaruh nyata terhadap respon kadar serat, sehingga nilai respon tersebut dapat digunakan untuk proses optimasi yaitu untuk mendapatkan produk dengan karakteristik yang optimum. Kadar serat yang dihasilkan dari setiap formulasi memiliki rentang nilai yang jauh berbeda atau berbeda nyata sehingga nilai kadar serat dapat digunakan untuk proses optimasi formula. 


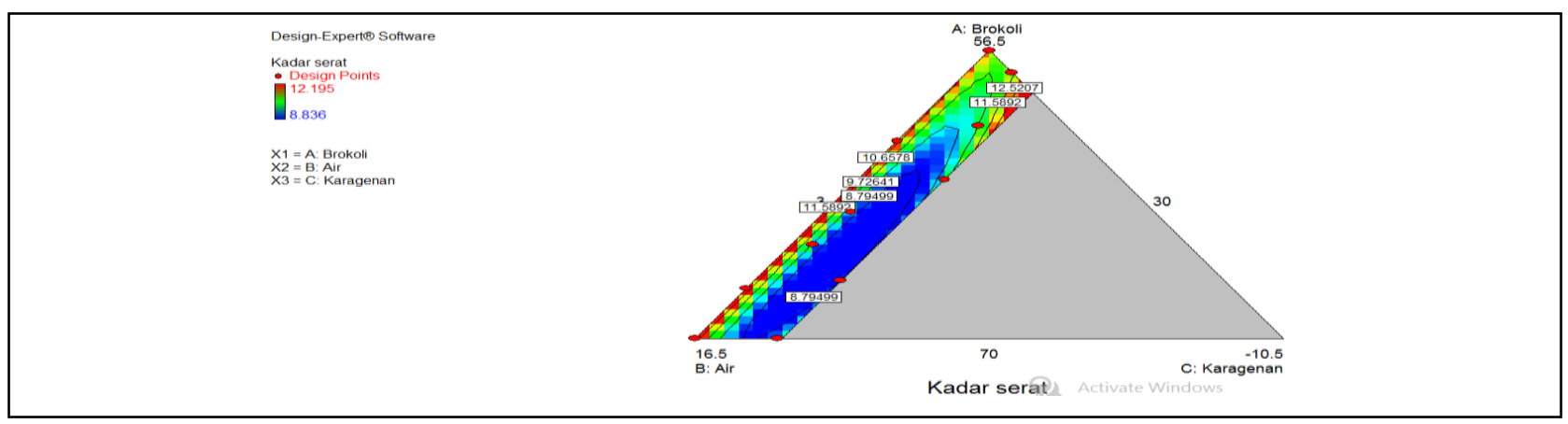

Gambar 4. Grafik Formulasi Optimal Berdasarkan Respon Kadar Serat

Grafik di atas menunjukkan formulasi optimal berdasarkan respon kadar serat yang diprediksi oleh grafik ini sebesar 11,94\% dimana batas bawah kadar serat dari keseluruhan formulasi yaitu $8,84 \%$ dan batas atas sebesar $12,19 \%$. Untuk mencapai nilai kadar serat sesuai dengan yang diprediksikan oleh program pada pengaplikasian produk Nori Brokoli dapat dilihat pada Gambar 19 dengan menggunakan brokoli $70 \%$, air $16,5 \%$, dan karagenan $3 \%$.

\section{Kadar Vitamin C}

Berdasarkan lampiran Tabel 38 ANOVA metode Mixture Design kadar Vitamin C Nori Brokoli, A menyatakan brokoli, B menyatakan air, dan C menyatakan karagenan. Term yang terdiri satu huruf dinamakan variabel tunggal menyatakan efek linear mendapatkan produk dengan karakteristik yang optimum. Kadar Vitamin C yang dihasilkan dari setiap formulasi memiliki rentang nilai yang cukup berjauhan sedangkan term yang terdiri dari dua huruf dinamakan dua variabel yang menyatakan efek interaksi.

Hasil analisis sidik ragam atau uji anova dapat dilihat dilampiran pada Tabel 35 menunjukkan formula yang dibuat significant / berpengaruh nyata (probabilitas $<0.05$ ) terhadap kadar vitamin $\mathrm{C}$ yang diuji dengan selang kepercayaan 95\%. Analisis sidik ragam yang dilakukan oleh program Design Expert metode Mixture design d-optimal pada nilai respon kimia kadar Vitamin C terhadap formula yang dibuat, menunjukkan model yang dibuat adalah signifikan (probabilitas $<0.05$ ), pada selang kepercayaan 95\% dengan nilai $\mathrm{p}=0,0363$. Artinya formula yang dibuat berpengaruh nyata terhadap respon uji skor kadar Vitamin C, sehingga nilai respon tersebut dapat digunakan untuk proses optimasi yaitu untuk atau berbeda nyata sehingga nilai kadar Vitamin C dapat digunakan untuk proses optimasi formulasi.

Grafik formulasi optimal berdasarkan respon kadar Vitamin C dapat dilihat pada Gambar 5.

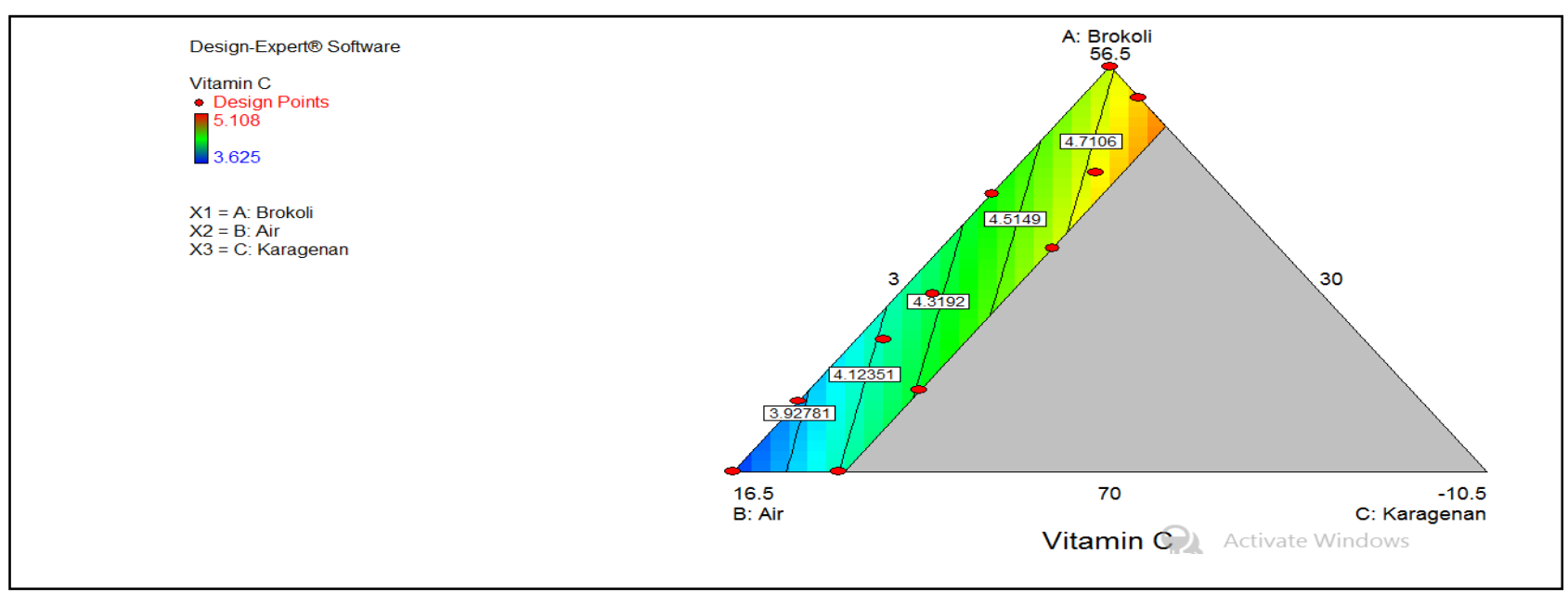

Gambar 5. Grafik Formulasi Optimal Berdasarkan Respon Kadar Vitamin C

Grafik di atas menunjukkan formulasi optimal berdasarkan respon kadar Vitamin $\mathrm{C}$ yang diprediksi oleh grafik ini sebesar 4,62 mg/100g sampel dimana batas bawah kadar Vitamin $\mathrm{C}$ dari keseluruhan formulasi yaitu $3,62 \mathrm{mg} / 100 \mathrm{~g}$ sampel dan batas atas sebesar $5,11 \mathrm{mg} / 100 \mathrm{~g}$ sampel. Untuk mencapai nilai kadar vitamin $\mathrm{C}$ sesuai dengan yang diprediksikan oleh program pada pengaplikasian produk Nori Brokoli 


\section{Hasil Uji Organoleptik Atribut Rasa}

Berdasarkan lampiran Tabel 41 ANOVA metode Mixture D-Optimal organoleptik atribut rasa produk Nori Brokoli, A menyatakan brokoli, B menyatakan air, dan $\mathrm{C}$ menyatakan karagenan. Term yang terdiri satu huruf dinamakan variabel tunggal menyatakan efek linear sedangkan term yang terdiri dari dua huruf dinamakan dua variabel yang menyatakan efek interaksi.

Hasil analisis sidik ragam atau uji anova dapat dilihat dilampiran pada Tabel 41 menunjukkan formula yang dibuat significan $t /$ berpengaruh nyata (probabilitas<0.05) terhadap respon organoleptic atribut rasa yang diuji dapat dilihat pada Gambar 19 dengan menggunakan brokoli $70 \%$, air $16,50 \%$, dan karagenan 3\%.

dengan selang kepercayaan $95 \%$. Analisis sidik ragam yang dilakukan oleh program Design Expert metode Mixture design d-optimal pada nilai respon organoleptik atribut rasa terhadap formula yang dibuat, menunjukkan model yang dibuat adalah signifikan (probabilitas<0.05), pada selang kepercayaan 95\% dengan nilai $\mathrm{p}=0,0171$. Artinya formula yang dibuat berpengaruh nyata terhadap respon uji hedonik respon rasa, sehingga nilai respon tersebut dapat digunakan untuk proses optimasi yaitu untuk mendapatkan produk dengan karakteristik yang optimum. Nilai respon organoleptik rasa yang dihasilkan dari setiap formulasi memiliki rentang nilai yang berbeda nyata sehingga nilai respon organoleptik rasa dapat digunakan untuk proses optimasi formulasi.

Grafik formulasi optimal berdasarkan atribut rasa dapat dilihat pada Gambar 6 .

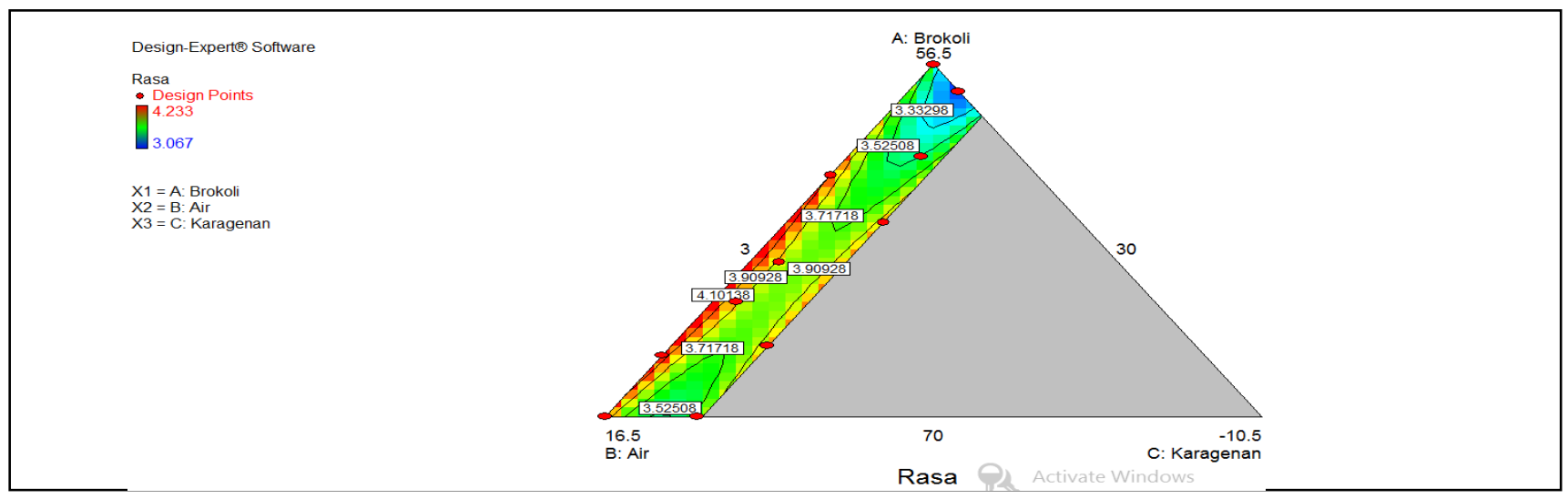

Gambar 6. Grafik Formulasi Optimal Berdasarkan Atribut Rasa

Grafik di atas menunjukkan formulasi optimal berdasarkan respon organoleptik atribut rasa yang diprediksi oleh grafik ini sebesar 4,10 dimana batas bawah respon organoleptik atribut rasa dari keseluruhan formulasi yaitu 3,07 dan batas atas sebesar 4.23. Untuk mencapai nilai respon organoleptik atribut rasa sesuai dengan yang diprediksikan oleh program pada pengaplikasian produk Nori Brokoli dapat dilihat pada Gambar 19 dengan menggunakan brokoli $70 \%$, air $16,5 \%$, dan karagenan $3 \%$.

\section{Atribut Tekstur}

Berdasarkan lampiran Tabel 44 ANOVA metode Mixture Design tekstur produk Nori Brokoli, A menyatakan brokoli, B menyatakan air, dan C menyatakan karagenan. Term yang terdiri satu huruf dinamakan variabel tunggal menyatakan efek linear

formulasi memiliki rentang nilai yang tidak jauh berbeda atau tidak berbeda nyata sehingga nilai tekstur tidak dapat digunakan untuk proses optimasi formulasi. sedangkan term yang terdiri dari dua huruf dinamakan dua variabel yang menyatakan efek interaksi.

Hasil analisis sidik ragam atau uji anova dapat dilihat dilampiran pada Tabel 44 menunjukkan formula yang dibuat not significant / tidak berpengaruh nyata (probabilitas $>0.05$ ) terhadap respon tekstur yang diuji dengan selang kepercayaan 95\%. Analisis sidik ragam yang dilakukan oleh program Design Expert metode Mixture Design D-Optimal pada nilai respon organoleptik atribut tekstur terhadap formula yang dibuat, menunjukkan model yang dibuat adalah tidak signifikan (probabilitas $>0.05$ ), pada selang kepercayaan 95\% dengan nilai $\mathrm{p}=0,4248$. Artinya formula yang dibuat tidak berpengaruh nyata terhadap respon uji hedonik tekstur, sehingga nilai respon tersebut tidak dapat digunakan untuk proses optimasi yaitu untuk mendapatkan produk dengan karakteristik yang optimum. Nilai tekstur yang dihasilkan dari setiap 
Grafik formulasi optimal berdasarkan atribut tekstur dapat dilihat pada Gambar 7.

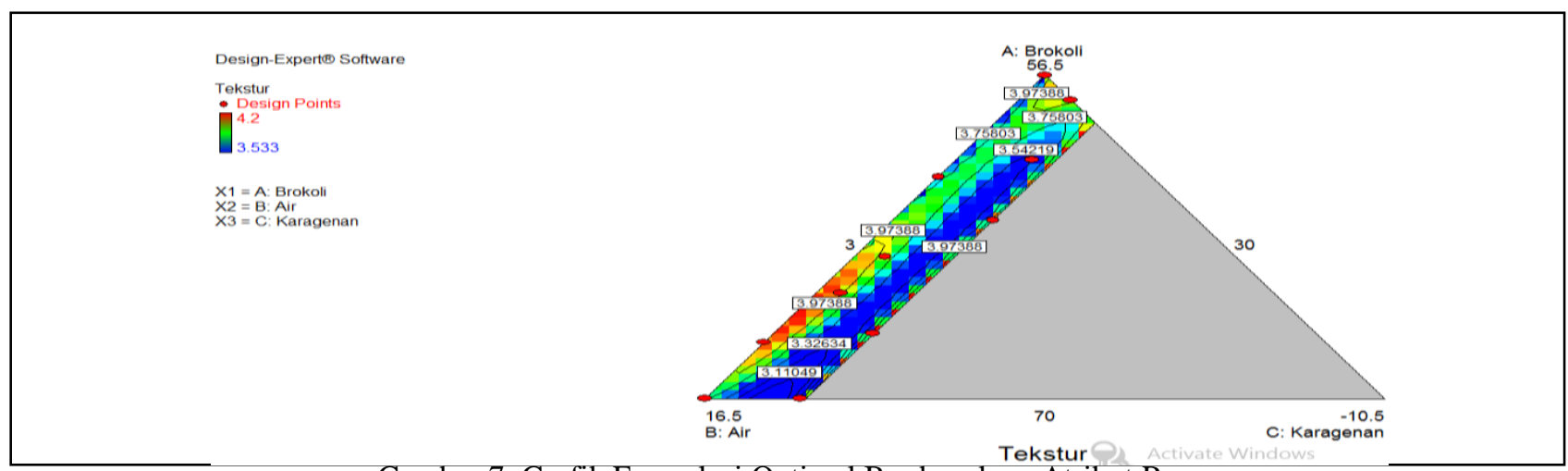

Gambar 7. Grafik Formulasi Optimal Berdasarkan Atribut Rasa

Grafik di atas menunjukkan formulasi optimal berdasarkan respon organoleptik tekstur yang diprediksi oleh grafik ini sebesar 3,56 dimana batas bawah respon organoleptik tekstur dari keseluruhan formulasi yaitu 3,27 dan batas atas sebesar 4,03. Untuk mencapai nilai respon organoleptik tekstur sesuai dengan yang diprediksikan oleh program pada pengaplikasian produk Nori Brokoli dapat dilihat pada Gambar 19 dengan menggunakan brokoli 70\%, air $16,5 \%$, dan karagenan $3 \%$.

\section{Atribut Aroma}

Berdasarkan lampiran Tabel 47 ANOVA metode Mixture Design respon organoleptik atribut aroma Nori Brokoli, A menyatakan brokoli, B menyatakan air, dan C menyatakan karagenan. Term yang terdiri satu huruf dinamakan variabel tunggal menyatakan efek linear sedangkan term yang terdiri dari dua huruf dinamakan dua variabel yang menyatakan efek interaksi.

Hasil analisis sidik ragam atau uji anova dapat dilihat dilampiran pada Tabel 47 menunjukkan formula yang dibuat not significant / tidak berpengaruh nyata (probabilitas<0.05) terhadap respon organoleptik atribut aroma yang diuji dengan selang kepercayaan 95\%. Analisis sidik ragam yang dilakukan oleh program Design Expert metode Mixture design $d$ optimal pada nilai respon organoleptik atribut aroma terhadap formula yang dibuat, menunjukkan model yang dibuat adalah tidak signifikan (probabilitas $<0.05$ ), pada selang kepercayaan 95\% dengan nilai $\mathrm{p}=0,3968$. Artinya formula yang dibuat tidak berpengaruh nyata terhadap uji hedonik respon aroma sehingga nilai respon tersebut tidak dapat digunakan untuk proses optimasi yaitu untuk mendapatkan produk dengan karakteristik yang optimum. Nilai repon organoleptik aroma yang dihasilkan dari setiap formulasi memiliki rentang nilai yang tidak jauh berbeda atau tidak berbeda nyata sehingga nilai respon organoleptik aroma tidak dapat digunakan untuk proses optimasi formulasi.

Grafik formulasi optimal berdasarkan atribut aroma dapat dilihat pada Gambar 8 .

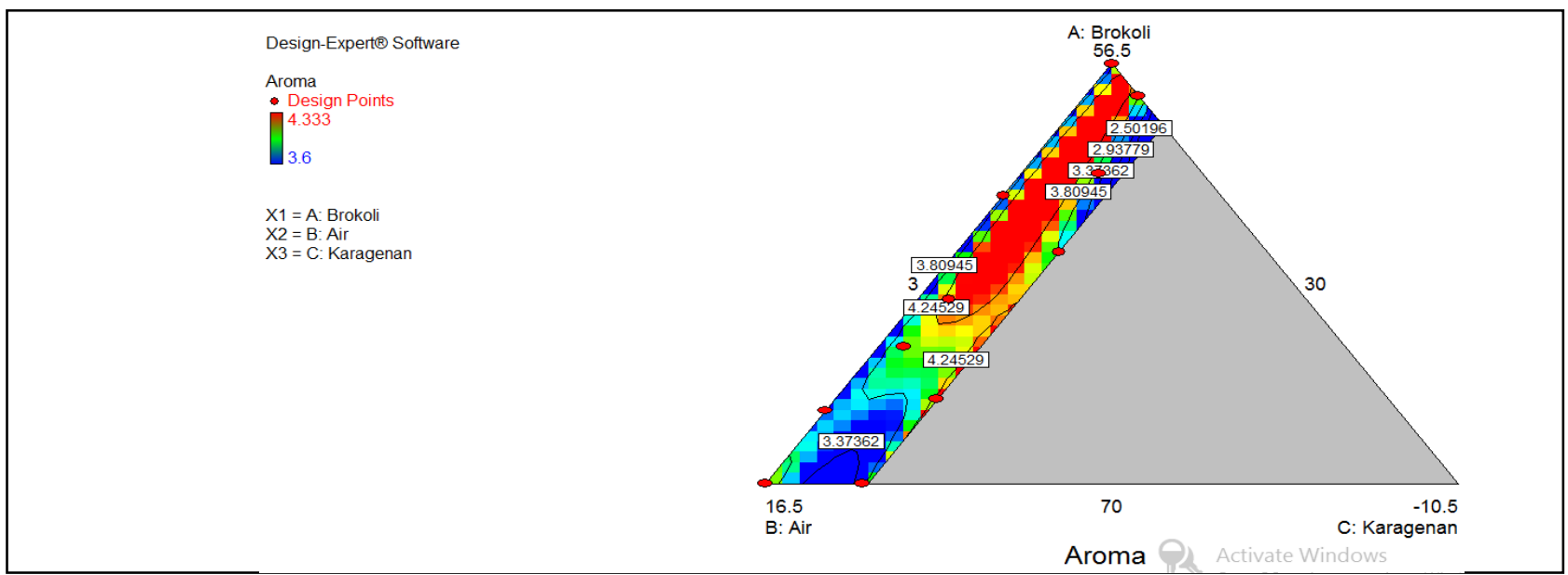

Gambar 8. Grafik Formulasi Optimal Berdasarkan Atribut Aroma 
Grafik di atas menunjukkan formulasi optimal berdasarkan organoleptik atribut aroma yang diprediksi oleh grafik ini sebesar 3,82 dimana batas bawah respon organoleptik atribut aroma keseluruhan formulasi yaitu 3,6 dan batas atas sebesar 4,33. Untuk mencapai nilai respon organoleptik atribut aroma sesuai dengan yang diprediksikan oleh program pada pengaplikasian produk Nori Brokoli dapat dilihat pada Gambar 19 dengan menggunakan brokoli $70 \%$, air $16,50 \%$, dan karagenan $3 \%$.

\section{Atribut Warna}

Berdasarkan lampiran Tabel 50 ANOVA metode Mixture Design respon organoleptik atribut warna Nori Brokoli, A menyatakan brokoli, B menyatakan air, dan $\mathrm{C}$ menyatakan karagenan. Term yang terdiri satu huruf dinamakan variabel tunggal menyatakan efek linear sedangkan term yang terdiri dari dua huruf dinamakan dua variabel yang menyatakan efek interaksi.

Hasil analisis sidik ragam atau uji anova dapat dilihat dilampiran pada Tabel 50 menunjukkan formula yang dibuat not significant / tidak berpengaruh nyata (probabilitas<0.05) terhadap respon organoleptik atribut warna yang diuji dengan selang kepercayaan $95 \%$. Analisis sidik ragam yang dilakukan oleh program Design Expert metode Mixture design $d$ optimal pada nilai respon organoleptik atribut warna terhadap formula yang dibuat, menunjukkan model yang dibuat adalah tidak signifikan (probabilitas $<0.05$ ), pada selang kepercayaan 95\% dengan nilai $\mathrm{p}=0,2174$. Artinya formula yang dibuat tidak berpengaruh nyata terhadap respon uji hedonik respon warna, sehingga nilai respon tersebut tidak dapat digunakan untuk proses optimasi yaitu untuk mendapatkan produk dengan karakteristik yang optimum. Nilai respon organoleptik warna yang dihasilkan dari setiap formulasi memiliki rentang nilai yang berdekatan dan tidak berbeda nyata sehingga nilai respon organoleptik warna tidak dapat digunakan untuk proses optimasi formulasi.

Grafik formulasi optimal berdasarkan atribut aroma dapat dilihat pada Gambar 9.

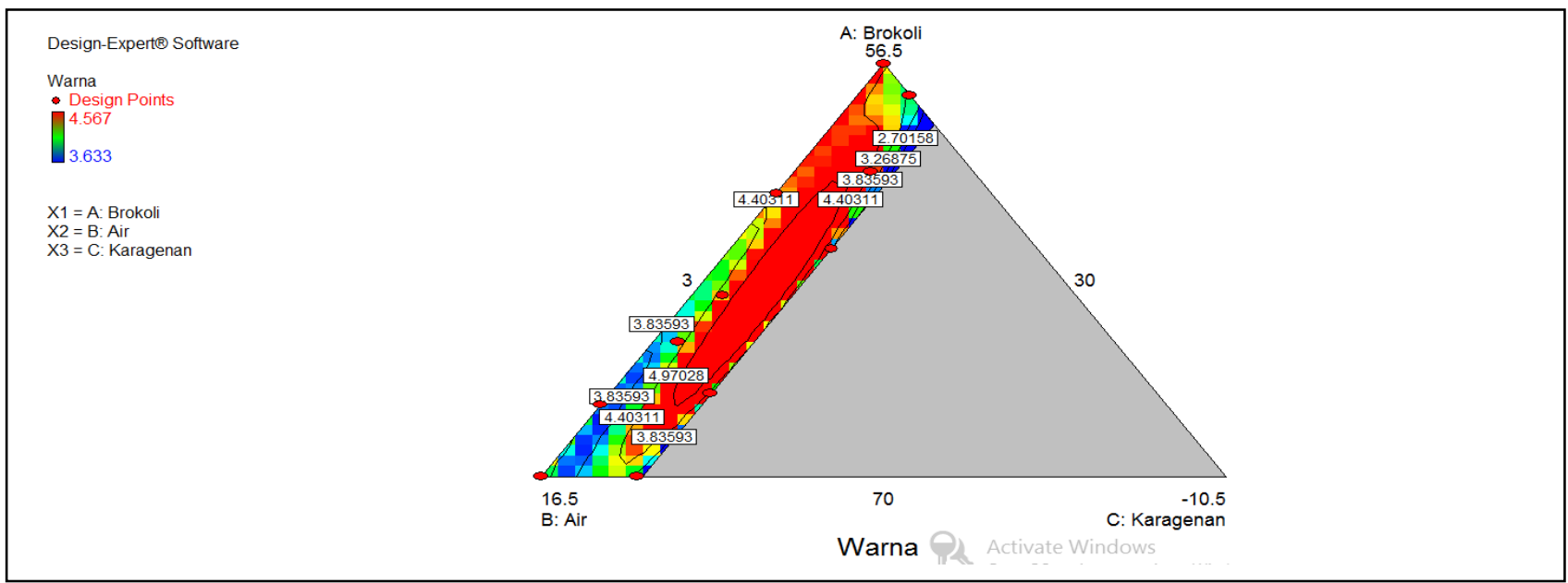

Gambar 9. Grafik Formulasi Optimal Berdasarkan Atribut Warna

Grafik di atas menunjukkan formulasi optimal berdasarkan respon organoleptik atribut warna yang diprediksi oleh grafik ini sebesar 3.27 dimana batas bawah respon organoleptik atribut warna dari keseluruhan formulasi yaitu 3,63 dan batas atas sebesar 4.57. Untuk mencapai nilai respon organoleptik atribut warna sesuai dengan yang diprediksikan oleh program pada pengaplikasian produk Nori Brokoli dapat dilihat pada Gambar 19 dengan menggunakan brokoli $70 \%$, air $16,50 \%$, dan karagenan $3 \%$.

\section{Formulasi Optimal Terpilih}

Formulasi terpilih merupakan solusi atau formulasi optimal yang diprediksikan oleh design expert metoda mixture d-optimal berdasarkan hasil analisis terhadap respon kimia (kadar air, kadar serat dan kadar Vitamin C) dan respon organoleptik (warna, rasa, aroma, dan tekstur). 
Tabel 5. Formulasi Optimal Nori Brokoli Menurut Program Design Expert

\begin{tabular}{|c|c|c|c|c|c|c|c|}
\hline Component & Name & Level & Low Level & High Level & Std. Dev. & Coding & \\
\hline A & Brokoli & 70.00 & 56.50 & 70.00 & 0.000 & Actual & \\
\hline B & Air & 16.50 & 16.50 & 30.00 & 0.000 & Actual & \\
\hline \multirow[t]{2}{*}{ c } & Karagenan & 3.00 & 1.00 & 3.00 & 0.000 & Actual & \\
\hline & Total $=$ & 89.50 & & & & & \\
\hline Response & Prediction & SE Mean & $95 \% \mathrm{Cl}$ low & $95 \% \mathrm{Cl}$ high & SE Pred & $95 \%$ PI low & 95\% PI high \\
\hline Kadar air & 9.89743 & 0.50 & 8.74 & 11.05 & 0.93 & 7.74 & 12.05 \\
\hline Kadar serat & 12.0859 & 0.47 & 10.78 & 13.39 & 0.70 & 10.13 & 14.04 \\
\hline Vitamin C & 3.73268 & 0.22 & 3.21 & 4.25 & 0.42 & 2.76 & 4.70 \\
\hline Tekstur & 3.78122 & 0.13 & 2.11 & 5.46 & 0.19 & 1.40 & 6.16 \\
\hline Rasa & 4.00798 & 0.14 & 3.66 & 4.36 & 0.21 & 3.47 & 4.54 \\
\hline Aroma & 4.05087 & 0.15 & 2.15 & 5.95 & 0.21 & 1.35 & 6.75 \\
\hline Warna & 4.02179 & 0.10 & 2.70 & 5.34 & 0.15 & 2.15 & 5.89 \\
\hline
\end{tabular}

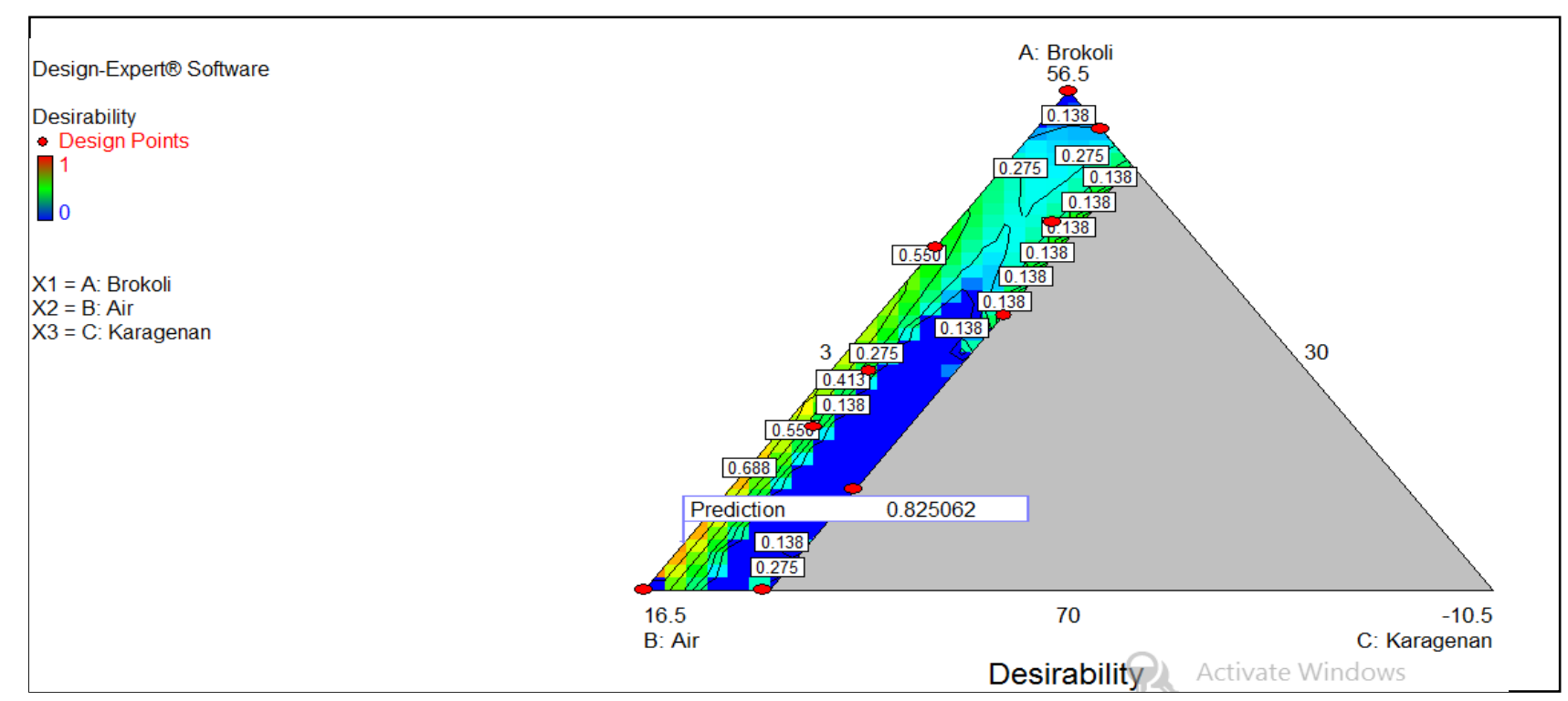

Gambar 10. Nilai Desaribility Formulasi Nori Brokoli

Ketepatan formulasi dan nilai masing-masing respon tersebut dapat dilihat pada desirability. Desirability adalah derajat ketepatan hasil solusi atau formulasi optimal. Semakin mendekati nilai satu maka semakin tinggi ketepatan formulasi. Pada penelitian nori brokoli ini dihasilkan sebesar 0,825 sehingga dapat disimpulkan berdasarkan nilai desirability tersebut maka formulasi yang dihasilkan memiliki nilai ketepatan yang cukup tinggi.
Berdasarkan desirability diatas formulasi optimal Nori Brokoli diperoleh 1 formulasi yang dapat dilihat pada Gambar 19 dengan rincian brokoli $70 \%$, air $16,50 \%$, dan karagenan 3\% dan formula tersebut diprediksikan oleh program akan menghasilkan produk dengan nilai kadar air 10,37\%, kadar serat $12,16 \%$, kadar vitamin C $3,82 \mathrm{mg} / 100 \mathrm{~g}$, rasa 4,10, tekstur 4,05, Aroma 3,78, dan warna 3,80 . 
Tabel 1. Perbandingan Hasil Analisis Design Expert Metode Mixture Design D-Optimal dengan Hasil Analisis Respon Kimia dan Respon Organoleptik Dilaboratorium Terhadap Nori Brokoli Terpilih

\begin{tabular}{|c|c|c|}
\hline Respon & Program & Laboratorium \\
\hline Kadar air & $10,37 \%$ & $11,44 \%$ \\
\hline Kadar serat & $12,16 \%$ & $5,38 \mathrm{mg} / 100 \mathrm{~g}$ \\
\hline Kadar vitamin C & $3,82 \mathrm{mg} / 100 \mathrm{~g}$ & 3,58 \\
\hline Rasa & 4,10 & 4,18 \\
\hline Tekstur & 4,05 & 3,77 \\
\hline Aroma & 3,78 & 4 \\
\hline
\end{tabular}

Perbandingan hasil program dan analisis laboratorium ini bermaksud untuk mengukur derajat ketepatan program selain daripada keterangan yang diberikan dalam bentuk desirability berjumlah 0,85 yang artinya baik. Berdasarkan data yang dihasilkan bahwa selisih dari kedua hasil ini tidak terlalu jauh sehingga dapat dikatakan program memiliki ketepatan yang baik dalam menetukan formulasi produk yang dapat dilihat dari perbandingan hasil analisis yang masih berdekatan dengan hasil data program

Berdasarkan penelitian yang telah dilakukan dapat disimpulkan sebagai berikut :

1. Brokoli, air, dan karagenan menurut program Design Expert metode mixture d-optimal dapat mengoptimumkan formula Nori Brokoli.

2. Program Design Expert metode Mixture D-Optimal memberikan 11 formulasi awal untuk analisis data produk Nori brokoli dengan variabel berubah yaitu brokoli, air dan karagenan, kemudian dihasilkan 1 formulasi terpilih yang optimal.

3. Berdasarkan hasil penelitian yang dilakukan terhadap 11 formulasi yang memberikan pengaruh signifikan yaitu respon kadar air , kadar serat, kadar Vitamin C, dan rasa, sedangkan yang memberikan pengaruh tidak signifikan yaitu respon tekstur, warna, dan aroma.

4. Formulasi optimal berdasarkan data dari ke-11 formulasi diatas untuk produk Nori brokoli diperoleh 1 formulasi terpilih yang ditawarkan dimana memiliki jumlah presentase tersebut yaitu brokoli $70 \%$, air 16,50\%, dan karagenan 3\%., dan bahan lainnya yang merupakan variabel tetap adalah garam $1,4 \%$, gula $3,3 \%$, minyak wijen $2,9 \%$, gliserol $0,9 \%$, dan udang kering $2 \%$

5. Hasil analisis dari formulasi optimal yang diprediksi oleh program Design Expert metode Mixture D-Optimal terhadap respon yaitu memiliki kadar air 10,37\%, kadar serat $12,16 \%$, kadar vitamin C 3,82mg, rasa 4,12, tekstur 4,05 aroma 3,78 , dan warna 3,80 .
6. Hasil analisis di laboratorium mendekati prediksi program Design Expert metode Mixture D-Optimal, dimana hasil analisis laboratorium formulasi optimal terhadap kadar air 12,63\%, kadar serat $11,48 \%$, kadar vitamin C 5,38mg/100, rasa 3,60, tekstur 4,20, aroma 3,80, dan warna 4 .

\section{DAFTAR PUSTAKA}

1. Andayani, R., L. Yovita, \& Maimunah. 2008. Penentuan aktivitas antioksidan, kadar fenolat total dan likopen pada buah Tomat (Solanum lycopersicum l). J. Sains dan Teknologi Farmasi,13(1): 31-37.

2. Anita, Z., F. Akbar., dan H. Hamidah. 2013. Pengaruh Penambahan Gliserol terhadap Sifat Mekanik Film Plastik Bioderadasi dari Pati Kulit Singkong. Jurnal Teknik Kimia USU, Vol 2, N0.2.

3. Anjarsari, B. 2010. Pangan Hewani Fisiologi Pasca Mortem dan Teknologi. Penerbit : Graha Ilmu, Yogyakarta.

4. Apriyance, P. 2014. Laporan Praktikum Teknologi Pengolahan Pangan Teknologi Pengolahan Buah dan Sayur Vegetable Leather (Daucus carota). Laporan praktikum. Universitas Pasundan. Bandung.

5. Ariyani, N. 2010. Formulasi Tepung Campuran Siap Pakai Berbahan Dasar Tapioka-Mocal dengan Penambahan Maltodekstrin Serta Aplikasinya Sebagai Tepung Pelapis Keripik Bayam. Skripsi . Fakultas Pertanian. Universitas Jenderal soedriman. Purwokerto.

6. ASEIBSSINDO, 2015. Data Perdagangan Sayuran Indonesia. Https://www.aseibssindo.co.id/doc/195723938/dat a-perdaganan-sayuran-indonesia. Diakses : 10 Oktober 2016.

7. AOAC. 1995. Official Methods of Analysis of the Association of Official Analytical Chemist. $18^{\text {th }}$ edition. Washington DC.

8. Belitz and Grosh. 1999. Food Chemistry. Springer Veralag Berlin heldenberg, New York. 
9. Buckle, K.A. 2009. Ilmu Pangan. Penerbit Univeristas Indonesia. Jakarta.

10. Budiman, R. P., 2014. Laporan Praktikum Teknologi Pengolahan Pangan Teknologi Pengolahan Buah dan Sayur Vegetable Leather. Laporan Praktikum. Universitas Pasundan. Bandung.

11. Dawezynski C, Rainer S, Gerhard J. 2007. Amino Acids,Fatty Acids and Dietary Fibre in Edible Seaweed Product. J.Food Chem. 103:891-899.

12. Fardiaz, D. 1989. Hidrokoloid. Laboratorium Kimia dan Biokimia pangan. Pusat Antar Universitas Pangan dan Gizi. Institut Pertanian Bogor. Bogor.

13. Handayani, L. 2014. Indeks Glikemik dan Beban Glikemik Vegetable Leather Brokoli (Brassica oleracea var. Italica) dengan Substitusi Inulin. Artikel Penelitian. Program Studi Ilmu Gizi, Fakultas Kedokteran Universitas Dipenogoro. Semarang.

14. Herudiyanto,. 2008. Pengaruh Imbangan Mangga Kweni (Mangifera odorata Griff.) dengan Wortel (Daucus carota L.) Serta Penambahan Gliserol Terhadap Beberapa Karakteristik Fruit Leather. Jurnal Teknorat. jurnal.unpad.ac.id/teknotan/article/view/4868.

Diakses : 13 Mei 2016.

15. Kartika, B., Hastuti, dan W. Supartono. 1998. Pedoman Uji Indrawi Bahan Pangan. Universitas Gajah Mada. Yogyakarta

16. Korringa P. 1976. Farming Marine organism Low In The Food Chain. Amsterdam, Oxford, New York: Elsevier Scientific Publishing Company.

17. Koswara S; Purwiyatno, H; dan Eko, H.P. 2002. Edible film. J Tekno Pangan dan Agroindustri. Volume 1 (12): 183-196

18. Kuda T, Makiko T, Hishi T, Araki Y. 2004. Antioxidant properties of dried "kayamo-nori" a brown alga Scytosiphon lomentaria (Scytosiphonales, Vinogradova. J. Food Chem. 89:617-622.

19. Kuda T, Hishi T, Maekawa S. 2005. Antioxidant properties of dried product of "haba-nori" an edible brown alga, Petalonioa binghamiae (J. Agardh) Vinogradova. J. Food Chem. 98:545-550.

20. Kuntari, A. N. 2015. Kombinasi Tepung Tapioka dan karagenan (Eucheuma cottonii Doty) Pada Proses Pembuatan Bakso Nabati dari Jamur Tiram Putih (Pleurotus ostreatus). Skripsi. Fakultas Teknobiologi. Universitas Atma Jaya Yogyakarta, Yogyakarta.

21. Krochta, J. m. and C. D. Mulder Johnson. 1997. Edible and Biodegradable Polymer Films : Challenges and opportunities, food technologi. 51 (2) : 62-74

22. Maulidiah, Nurul Laili. 2009. Sifat Organoleptik Minyak Wijen yang Diekstrak dengan
Menggunakan Pelarut Minyak yang Berbeda. Tugas Akhir, Program Studi Tata Boga, Jurusan Teknologi Industri, Fakultas Teknik, Universitas Negeri Malang. Malang.

23. Mujiarto, I. 2005. Sifat dan Karakteristik Material Plastik dan Bahan Aditif. Jurnal Traksi, 3 (2).

24. Permadi, V. 2014. Pengaruh Jenis Daun Cincau dan konsentrasi Bahan Penstabil Terhadap Karakteristik Artifisial Nori Bayam (Amaranthaceae Hybridus). Skripsi. Fakultas Teknik. Universitas Pasundan. Bandung.

25. Puspitasari. S. A.P. 2012. Minyak Wijen. Fakultas Kedokteran. Universitas Dipenogoro. Semarang.

26. Ramadhan, K. 2016. Pengaruh Penambahan Gliserol Terhadap Mutu Fruit Leather kulit Buah Naga Daging Super Merah Selama Proses Penyimpanan. Sinopsis Penelitian Tesis.

27. Rachmawaty, H. 2014. Senyawa-Senyawa dalam sayuran brokoli. Skripsi. Fakultas Petanian Unpad, Bandung

28. Rukmana, R. 1996. Manfaat-Manfaat Sayuran Brokoli Bagi Tubuh. Artikel Kimia Pangan. Yogyakarta. Kanisius

29. Samsuar. 2007. Karakteristik Karagenan Rumput Laut Eucheuma cottonii Pada Berbagai Umur Panen, Konsentrasi KOH dan Lama Ekstraksi. Skripsi. Jurusan Teknologi Pertanian. Institut Pertanian Bogor. Bogor.

30. Sidi, N. C., E. Widowati., A. Nursiwi. 2014. Pengaruh Penambahan Karagenan pada Karakteristik Fisikokimia dan Sensoris Fruit Leather nanas (Ananas comosus L.Merr.) dan Wortel ( Daucus carota). Jurnal Aplikasi Teknologi Pangan 3 (4) 2014.

31. Soekarto, T. dan Soewarno, S. 1985. Penilaian Organoleptik Untuk Industri Pangan dan Hasil Pertanian. Penerbit : Bharata Karya Aksara, Jakarta.

32. Suherman, A. 2012. Penggunaan Karagenan Sebagai penstabil. Https://adesuherman.wordpress.com/. Diakses : 4 April 2016.

33. Suwarto,A. 2010. 9 Buah dan Sayur Sakti. Yogyakarta : Penerbit Liberplus. 